\title{
From sustainable development through green growth to sustainable development plus
}

\author{
Godwell Nhamo
}

\begin{abstract}
From sustainable development (SD) through green growth to sustainable development plus (SD+)! Does the ' + ' really matter? This is the question that brings life to this article and the answer is: YES, it does. The ' + ' makes a huge difference especially for developing countries such as those from Africa that for a long time have not been fully brought on board in shaping global discourses and the preferred future global development agenda. This article argues that the time has come for globally privileged countries of the North to realize that operationalizing 'The Future We Want' after Rio+20 demands that developing countries be accorded unpolluted space to contribute to providing answers to difficult and elusive questions on the unsustainable ways of the past development paradigms. Among such questions are: When will the issue of resource intensive development and overconsumption be finally answered? Can green growth transition be part of the solution? How will a post 2015 framework best address the needs of developing countries? The conclusion is that SD+ signals a deeper, wider and knowledge-based understanding of global (UN) sustainable perspectives that result in global citizens understanding The Future We Do Not Want.
\end{abstract}

Key words: Ecology in Africa; green growth; sustainable development; SD+; The Future We Want

\section{Introduction}

The Rio+ 20 outcomes document, 'The Future We Want', indirectly and strongly confirms the known fact that where we are coming from as a global village is littered with elements of The Past We Do Not Want. This article audits developments in the past 22 years since Rio 1992 when the sustainable development agenda was firmly placed on the global map, through the green growth discourses that followed the 2008 financial crisis, to Rio+20 when the world confirmed its allegiance to continue finding sustainable development 
solutions and to building 'The Future We Want ', up to the post 2015 agenda. Our past reminds us of slave trade, colonialism, the partitioning of and scramble for Africa and other developing continents, apartheid, wars of greed and overconsumption, violation of human rights (even from those nations that profess to be sustainable development champions), manipulation, challenges of the gross domestic product - GDP ('Gross Domestic Problem' as Lorenzo Fioramonti puts it in his recent book (Fioramonti 2013), hunger and malnutrition, financial crises, global warming and climate change, creation of too powerful institutions such as the World Bank, International Monetary Fund (IMF), denied and delayed compensation for loss and damage by stronger nations, rampant corruption and many other challenges too numerous to mention here.

It is the foregoing aspects that make one think deeply of our journey from Our Common Future to The Future We Want or, it should be said, The Future We Do Not Want. True, it would be hypocritical for us not to acknowledge the wonderful innovations and discoveries that have come from the past. The telephone, the cell phone, tablet, steam and combustion engines, the aeroplane, the rocket (military or otherwise), nuclear energy, information technology (particularly the Internet and social media), high speed train, organ transplants (including the heart) magnificent high-rise buildings, DNA, cloning, X-Ray, genetically modified organisms (GMO), the satellite, electric motor, the discoveries are also too many to mention. Sadly, this human sophistication and artisanship have failed to eradicate intergenerational poverty and bring happiness to the earth's inhabitants, particularly those in Africa and other underdeveloped parts of the world. Uprisings, upon uprisings! Talk of the so-called Arab Spring. However, the world has now set its eyes on green growth, a development paradigm so opposed to the old growth path which was resource intensive (African Development Bank- AfDB 2013) to one that is resource efficient. 
The sophistication and artisanship have brought wealth and happiness to a select few. o, we can confirm that the sustainable development of old has not done what needs to be done- distribute wealth equitably, eradicate poverty, end wars and save the environment (the natural capital base). It is against such a background that this work advances the notion of sustainable development plus (SD+). To fulfil the demands of the SD+ agenda, global citizens and leadership need to regard sustainable development as both a moral and ethical issue. Therefore, SD+ goes beyond the common three pillars of sustainability, namely, economic, environmental and social sustainability. Human beings simply need to do the right thing. We need new deliberation platforms and a world where equity is central to everything. Some nations and individuals cannot continue to be more equal and quench their thirst through oppressing the poor. The moral compass has been lost and greedy superpower nations must lead the way to find this compass.

This article is divided into seven sections. The next section focuses on the methodology that was followed. Section 3 reflects on the period of the landmark publication, 'Our Common Future', whilst Section 4 draws insights from discourses on transition from reducing emissions from deforestation (RED), through reducing emissions from deforestation and forest degradation (REDD), to REDD+. Section 5 is dedicated to the green growth transition pathway and Section 6 presents the proposed SD+ concept. The last section is the conclusion.

\section{Research methodology}

The article asks one major question: what form will the common and globally accepted concept of sustainable development take into the future? This question arises against the background of the Rio+20 outcomes that sets the world firmly towards a renewed and somehow solid platform to continue along the paths of old in terms of sustainability. It takes mainly a literature survey approach and analyses the discourse on the three main subject areas: Our Common Future, green growth and SD+ (Van Dijk 1997). With thousands of publications on the concept of sustainable development and thousands more emerging on the concept of green growth, the future the world wants and the post Millennium Development 
Goals (MDGs) agenda, the author decided to take time to immerse himself in the richness of what is already available. After this exercise, new ideas were crafted that try to link the old to the new and find spaces for further discourse. Following Sandig and Selting (1997), this critical review and synthesis of existing literature will inform global players of the need for a smooth migration from sustainable development through the green growth agenda to the SD+ epoch. The emphasis is that the article does not set dichotomies between the old views and the new, but seeks to blend the old with the interim and the new and vice versa.

\section{Our common future: Not good enough?}

Since 1987, the global leadership has accepted the publication and recommendations from one of the commonly cited reports providing a definition of sustainable development: 'Our Common Future' by the Brundtland Commission (Dixon and Fallon

1989). Sustainable development is defined in 'Our Common Future' as 'development that meets the needs of the current generations without compromising the needs of future generations' (United Nations 1987: 11). Twenty-five years down the line, world leaders have evaluated progress on sustainable development addressed in 'Our Common Future' through the Rio+20 Summit in 2012. The recommendations sought to witness the environment and social agendas fully harmonized with the economic development agenda. This resulted in the widely accepted three pillars of sustainability: economic, environmental and social sustainability. Over the years, a crosscutting pillar emerged, the governance pillar (Nhamo and Inyang 2011). Although many positives came out of 'Our Common Future', the document has been criticized, particularly on the definitions and the goals it sought to achieve.

Drawing from the discourse in 'Our Common Future' and writing in the late 1980s, Dixon and Fallon (1989) conclude that the concept of sustainability became development rhetoric. This was owing to the fact that the Brundtland Commission on Environment and Development applied sustainable development as the main organizing string. In trying to trace the origin of the concept, the authors switch to the Latin equivalent of the word 'sustain', 'sustenere'. Sustenere implies 'to hold up or keep elevated' (op. cit.: 74) and in 
the context of natural resources management this means to maintain or prolong productive use of resources. Hueting (1990) saw the Brundtland Report as containing conflicting goals. In his view, the report somehow overstressed the need to protect the environment and not the living conditions of a populace that need to be improved when the environment is exploited.

To implement sustainable development, the Rio Earth Summit that took place in Brazil came up with Agenda 21 (Nhamo and Inyang 2011). This was an agenda for the $21^{\prime 1}$ century that would have witnessed the implementation of sustainable development leading to sustainability. However, progress was limited as many countries and authorities battled with pinning down the notion of sustainable development into action on the ground. To this end, the economic pillar of sustainable development continued to dominate (Fioramonti 2013). As indicated in the introduction, there are outstanding issues from the 'Our Common Future' epoch; issues such as how to address overconsumption and greed, superpower and/or big brother syndrome, elusive poverty, joblessness and exclusiveness. These are issues that global leaders are still battling with today.

However, one might not take away the credit from Our Common Future, that it got the world talking sustainability. This is evident today as, 25 years later, global leaders are still embedded in 'Our Common Future's' terminology such as The Future We Want from Rio+20 (Rio Pavilion 2012) and sustainable development. To further prepare the platform leading to $S D+$, the next section discusses transition from reducing emissions from deforestation (RED) through reducing emissions from deforestation and forest degradation (REDD) to REDD+ on climate change global negotiation platforms.

\section{From RED to REDD+ in climate negotiations}

Transition from sustainable development to SD+ can draw lessons from the transition that took place from reducing emissions from deforestation (RED), through reducing emissions from deforestation and forest degradation (REDD), to reducing emissions from deforestation and forest degradation plus (REDD+) (see Figure 1 below). All this took place within the sustainability context in the United Nations Framework Convention on Climate Change (UNFCCC). Each 
year the Conference of the Parties (COP) to the UNFCCC meet to deliberate developments concerned with the need to address climate change. RED first featured during one such COP: COPIl that took place in Montreal, Canada in 2005 (Hueting 1990). This was mainly driven by the need to have consumers pay for environmental services provided by forests and to provide compensation to communities that would have managed to preserve their forests. This provided an additional incentive for compensating those from developing countries for such work. The developed countries would pay for the services whilst simultaneously assisting in bridging the divide between them and countries of the south over general disagreements in the UNFCCC regarding the polluter pays fundamental (Nhamo 2011). Whilst the original idea of simple compensation for environmental services from forest conservation still holds, the debates shifted significantly as negotiators became more sophisticated both technically and politically, particularly drawing experiences from the 1997 Kyoto Protocol - an implementation framework to the UNFCCC. Although global leaders identified the need to have a separate agreement and/or convention on forests during the 1992 Rio Earth Summit, consensus could not be reached on such a comprehensive framework until COP11. It was Costa Rica and Papua New Guinea that brought back the RED agenda into climate negotiations during COP11 (Brunner et al. 2010). This was done on behalf of the Coalition of Rainforest Nations.

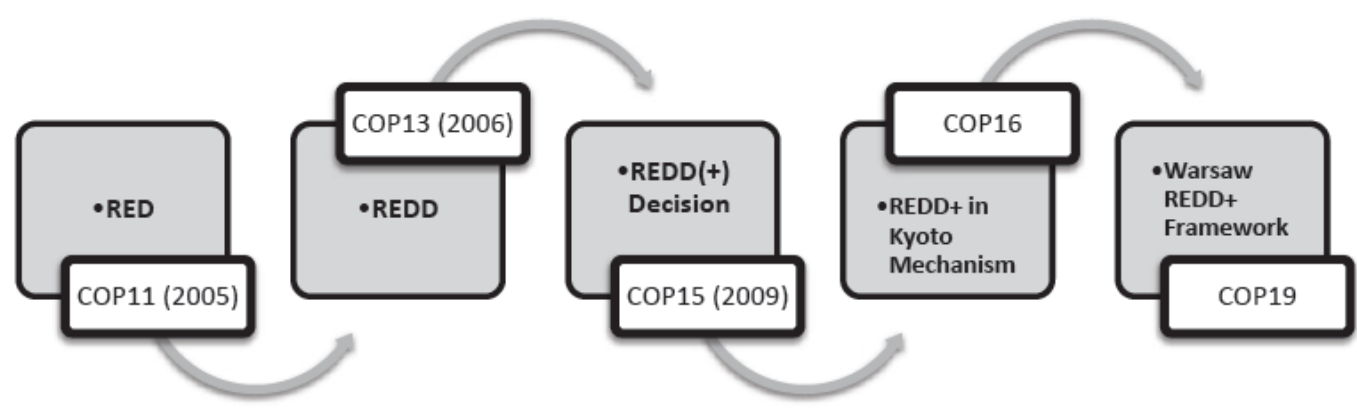

Figure 1: Transition from RED to REDD+ (Source: Author [based on Pistorius 2012])

Between 2005 (COPII) and 2007 (COP13), two expert projects on RED were undertaken and debates centred on the need to expand RED to include issues on forest degradation (Pistorius 2012). This was deemed to represent an additional 
large source of greenhouse gas (GHG) emissions that are harmful to our environment. This resulted in an additional ' $D$ ' in REDD. This extra ' $D$ ' focused mainly on overgrazing (Brunner et al., 2010). However, debates did not stop, as India and China were of the view that REDD would promote compensation mainly for the protection of forests whilst excluding other utilities that developing countries need such as access to forests for subsistence (Nhamo 2011). As a result, the inclusion of the ' + ' elements in REDD during COP15 followed (Corbera and Schroeder 2011). Other countries such as the USA viewed the ' + ' activities as having market-based mechanisms that would permit carbon offsetting although Brazil, which favoured a fund-based approach, continued to oppose this thinking and proposition (Pistorius 2012). Following a decision on REDD+ during COP15, a follow-up COP in Cancun, Mexico, incorporated REDD+ under the Kyoto Protocol mechanism (Boyle et al. 2011). This meant that REDD+ now qualified for carbon trading credits on the carbon market. During COP19 in Warsaw, the International Institute for Sustainable Development (IISD) (2013) reported that the Warsaw REDD+ Framework had been reached. The Warsaw REDD+ Framework (Third World Network 2013a) addresses aspects on financing, institutional arrangements and methodological package. These issues are due for finalization during COP2O.

There are a number of lessons that can be drawn from the transition from RED through REDD to REDD+ that may inform discussions on transition from sustainable development through green economy to SD+. Although REDD+ remains contested, it is credited with bringing aspects such as local participation to utilizing resources from RED and REDD and hybrid approaches fusing both market-based and fund- based approaches. These are seen as co-benefits for the livelihood particularly of the indigenous people and safeguards represented by the inclusion of the ' + ' witnessed during COP15 in Copenhagen (Nhamo 2010). In REDD+, stakeholders had to address aspects pertaining to risks associated with land grabbing, customary rights, and free prior and informed consent regarding indigenous and local communities involved in REDD+. Stakeholders engage in positives including 'conservation, sustainable management of forests, and enhancement of carbon stocks in developing 
countries' (Boyle et al. 2011: 1). In as much as REDD+ has been generally accepted globally, challenges still exist, including how to measure, monitor and verify (MRV) the amount of GHG sequestrated; determining additions under the Kyoto Protocol mechanism and permanence and leakage (Venter and Koh 2012).

Finance remains a key issue in REDD+. The World Bank Forest Carbon Partnership Facility (FCPF) is one such funding mechanism and countries must be prepared if they are to get the funding. The FCPF readiness mechanism stipulates that these countries should develop a Readiness Plan Idea Note (R-PIN). Such an R-PIN details how the host country of a project under the FCPF addresses good governance of forests. In a study on 25 approved R-PINs, Davis et al. (2009) focused on 17 pillars of the R-PIN which for ease of analysis they grouped under six basic processes. The six basic processes included:

- Law and policy development

- Land tenure administration and enforcement

- Forest management

- Forest monitoring

- Law enforcement and

- Forest revenue distribution and benefit sharing.

Outdated and/or unclear forest policies and laws, poor policy harmonization and mainstreaming across sectors, unclear land tenure rights and complex regulatory systems for law enforcement emerged as key readiness drawbacks for 25 countries in the case study. African countries included in the research were: Cameroon, Congo, the DRC, Ethiopia, Gabon, Ghana, Kenya, Liberia, Madagascar and Uganda (Davis et al. 2009). The challenges highlighted here also apply in the SD+ generation.

Overall, one concludes that the movements from RED, through REDD, to REDD+ clarified issues of inclusiveness, especially on how to deal with the less powerful and often marginalized indigenous and local communities from developing countries. The movement also included missing links from a single ' $D$ ' to two 'Ds' and a plus. This history lesson still remains relevant today as we move towards and 
embrace the SD+ phenomenon. REDD+ challenges also provide red flags on how to monitor and implement SD+ as well as identify game changers such as the actions of Costa Rica and Papua New Guinea to bring back the RED debates into climate negotiations on behalf of the Coalition of Rainforest Nations in Montreal during COP11. The next section focuses on green growth with the aim of making a bridge to the SD+ discourses.

\section{The green growth pathway}

The green growth pathway may be traced from the 2008 financial crises (Nhamo 2013). Following the financial crisis, world leaders sought to have a one-stop shop for addressing global challenges including the energy, water, and food and climate change crises. Since the energy and climate change crises were dominant then, global leaders thought that a low carbon development pathway would be one such good solution. This thinking embedded a green mini 'revolution' within the so-called financial stimulus packages. Countries that designated green stimulus financial packages diverted certain percentages of their stimulus spending towards low carbon development initiatives that addressed simultaneously climate change and energy crises. Later in 2009, the United Nations Environment Programme (UNEP) established the Green Economy Initiative as a major mechanism for addressing the multi-faceted challenges that included climate change, financial crisis, energy crisis and many other crises. To this end, the concept green economy grew phenomenally with new names and sub-elements emerging including: inclusive green growth, green growth, climate resilient development, low carbon development etc. (ibid.). Since then, a number of green growth national policies and strategies on green growth have emerged including those from South Korea, Ethiopia, Britain, Rwanda, Colombia, Ireland, China, Germany, Mexico, Colombia as well as a number of states in the Americas (Global Green Growth Best Practice Initiative 2014).

After a few years of discourse and the implementation of green economy transition projects, most of which were in the energy sector, UNEPpublished a landmark document entitled 'Towards a green economy: Pathways to sustainable development and poverty eradication' in 2011. In the document, UNEP (2011) 
advocates a set of five intertwined enabling conditions for green economy (applied in this article as interchangeable with green growth). These conditions are finance, governance, market, infrastructure and information. Within a green economy, DeSombre (2011) places responsibility on institutions. In her view, environmental and other institutions play a critical role in generating and disseminating green economy information. Such institutions assist in shaping the agenda both at national and international negotiation platforms. States commit to certain decisions on green economy and these must be implemented at the national level once ratified. The International Chamber of Commerce (ICC) (2011) identifies 10 high level conditions for a transition to a green economy based on the conventional pillars of sustainable development: economic sustainability, environmental sustainability and social sustainability. These 10 conditions are so interwoven that missing one could be a line for a weak link and among such is included education and skills development (Figure 2). In 2009, Rwanda President Paul Kagame advised that: 
The environment is our life-blood; indeed the real surprise is not that ministries of finance are now talking to ministries of environment-but that it has actually taken this long. Even when we look beyond agriculture, tourism, mineral wealth and fisheries, our economies depend critically on good environmental stewardship. (Smith School of Enterprise and the Environment 2010: ii)

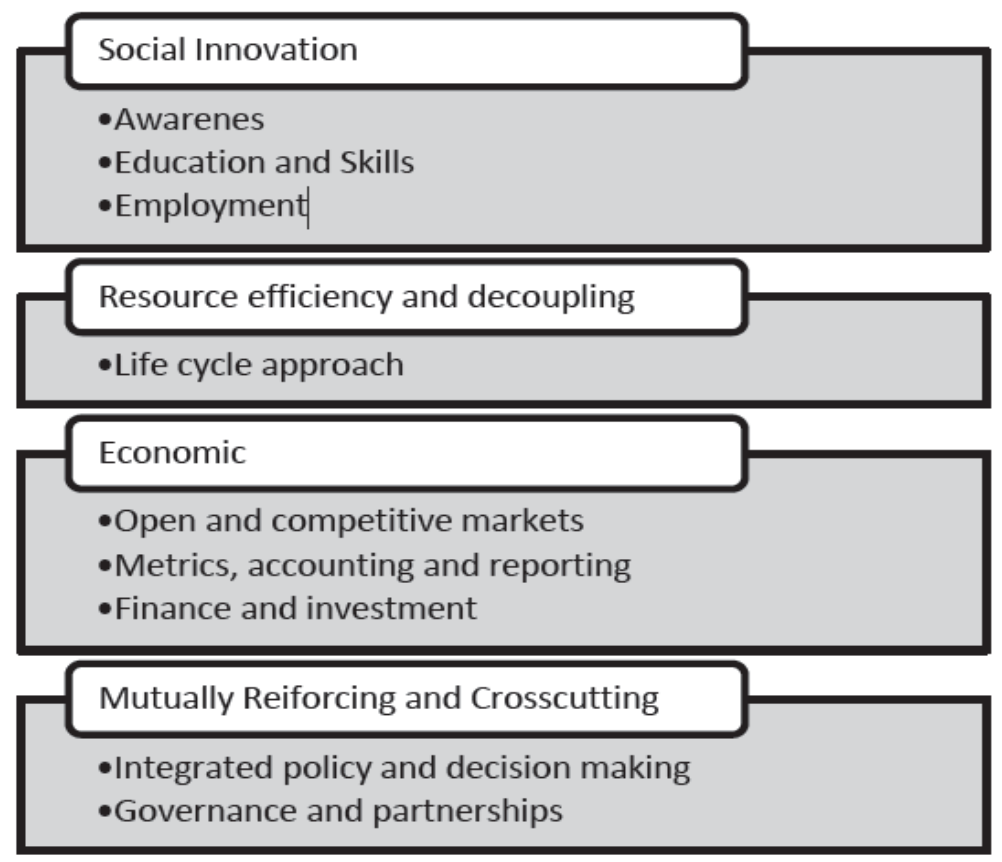

Figure 2: Ten green economy high level conditions (Source: Author [Based on ICC 2011: 4-6])

Green and McCann (2011) are disturbed by lack of green economy research on how this economy impacts on organizations' strategy, structure and culture. To this end, they conclude the world is in search of new theories that will result in the development of appropriate green economy leadership. In transforming leadership in a green economy, three elements are fundamental in the authors' view: culture, leadership and values. Innovation and technology transfer has its sub-conditions in a green economy. Tawney and Weischer (2011) set six conditions for supporting innovation and technology transfer in a green economy. Such conditions must witness priority setting and coordination; joint research, development and demonstration; sharing information and knowledge; capacity building; provision of finance; and supporting hubs and networks. Capacity building includes both institutional and individual capacity, a critical aspect for developing countries like those in Africa. 
From Rio+20, the green economy emerged as a means of attaining sustainable development and poverty eradication (UNCSD 2012). However, readiness in climate financing is a critical aspect in green economy transition. The UNDP has prepared a document dealing with readiness for climate finance. In the document, the UNDP (2012: ii) defines what it implies by climate finance readiness which it says is:

... the capacities of countries to plan for, access, deliver, and monitor and report on climate finance, both international and domestic, in ways that are catalytic and fully integrated with national development priorities and achievement of the :MDGs.

From the work by the Global Green Growth Best Practice Initiative (2014), it emerges that a range of issues is addressed, namely, high level visions and targets, benefits, prioritization of options and pathways, policy designs, financing strategies, public- private collaboration as well as national and sub-national integration. All these facets are embedded in the planning and coordination processes that include monitoring and evaluation. However, financing green growth remains an issue requiring more focus.

The African Climate Finance Hub (2012) believes that climate finance readiness is shaped by national circumstances and contexts. Hence it is necessary to realize the interwoven political and economic dimensions in a particular country when making efforts to strengthen institutions and processes dealing with climate finance readiness. The finer details contained in each of the four stages highlighted in the definition are presented in Figure 3. The UNDP (2012) also notes that although the proposed framework is applicable at various spatial scales, it must not be seen as a one size fits all approach and model. 


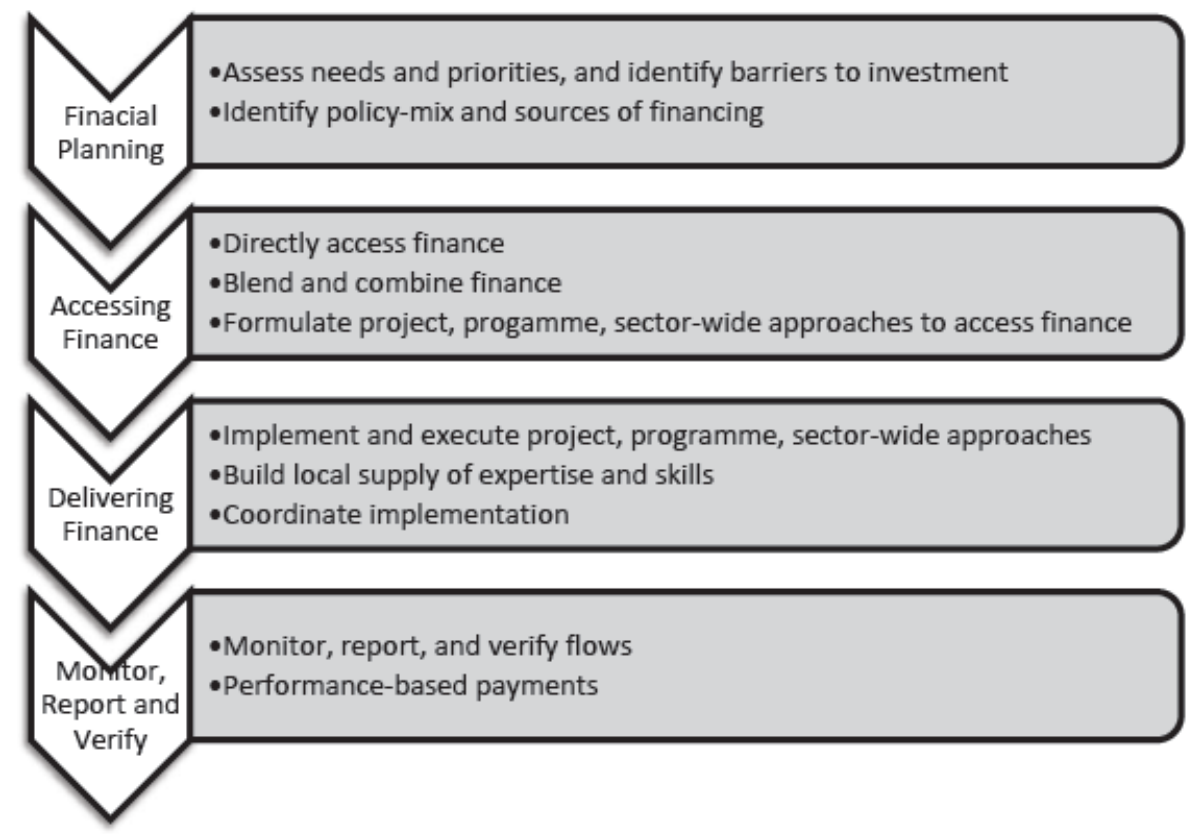

Figure 3: Elements of climate finance readiness (Source: UNDP 2012: 5)

In its hybrid climate finance readiness model that draws from the UNDP model, the African Climate Finance Hub (2012) identifies what it considers as principles and core components to take note of in the SD+ period. In terms of principles, climate finance readiness must be relative (to social, economic and political circumstances); responsive (to the need, priorities and challenges); and reasonable (in identifying key issues and practical steps). The core components then draw directly from the UNDP (2012) model and the hybrid model was applied to assessing climate finance readiness in Namibia and Zambia.

Regarding the green economy funding mechanisms, the Development Bank of Southern Africa (DBSA) (2011) came up with five typical funding mechanisms. These are: international donors, public finance, capital markets, climate finance instruments as well as equity and venture capital. However, national strategic implementing partners will be required and these were highlighted as the Industrial Development Corporation (IDC), commercial banks and the DBSA. These partners will have streamlined responsibilities. Six climate and green economy funding 
mechanisms were identified in the National Climate Change Response White Paper of South Africa (DEA2011). These included public finance; development finance (the DBSA, IDC, Land Bank and Khula Enterprises), private banks and microfinance; investors like asset managers, venture capital and private equity firms; insurers; as well as international and corporate grant- providers. Having outlined the discourse deliberating on green growth pathways, the next section is dedicated to a precise discussion on the proposed notion of SD+. In this section, game changers resulting in multiple tipping points towards the SD+ notion are presented.

\section{Sustainable development PLUS}

It is difficult to discuss the notion of SD+ without touching on game changers. Game changers are a common but difficult terrain to grasp. De Cock et al. (2011) provide a synopsis of what game changers are. In their view, game changers 'are radical innovations that fundamentally change how something is done, thought about or approached' (De Cock et al. 2011: S61); in the context of this article, this is the SD+ notion. In fact, De Cock and his co-authors indicate that such game changers could be political, social or economic events. Environmental is a fourth category that should be added. Examples cited by the authors include cellular telephones, the Internet and social media. To this list, should be added natural phenomena like global warming, climate change and the possible death of the combustion engine in the near future. Zheng (2010) identifies the discovery of DNA in the middle of the 20th century as one of the global game changers. Game changers also relate to tipping points; phenomena that overcome the status quo by creating instability (Cains 2004) that requires seeking, either naturally or through the human power, new equilibriums. Tipping points are not identifiable until a major disaster occurs and a number of such tipping points may have a cumulative effect leading to the displacement of the status quo. Known examples, as is common knowledge now, include the 2008 global financial crisis and the so-called Arab Spring. Hence, the green growth agenda certainly qualifies as one of the game changers leading to the SD+ agenda. In the introduction, game changers are mentioned and categorized under: old but 
still relevant; new and relatively new; and possible future game changers. This observation fits well with the foregoing discussion. Some of the game changers this article identifies are presented in Figure 4, below.

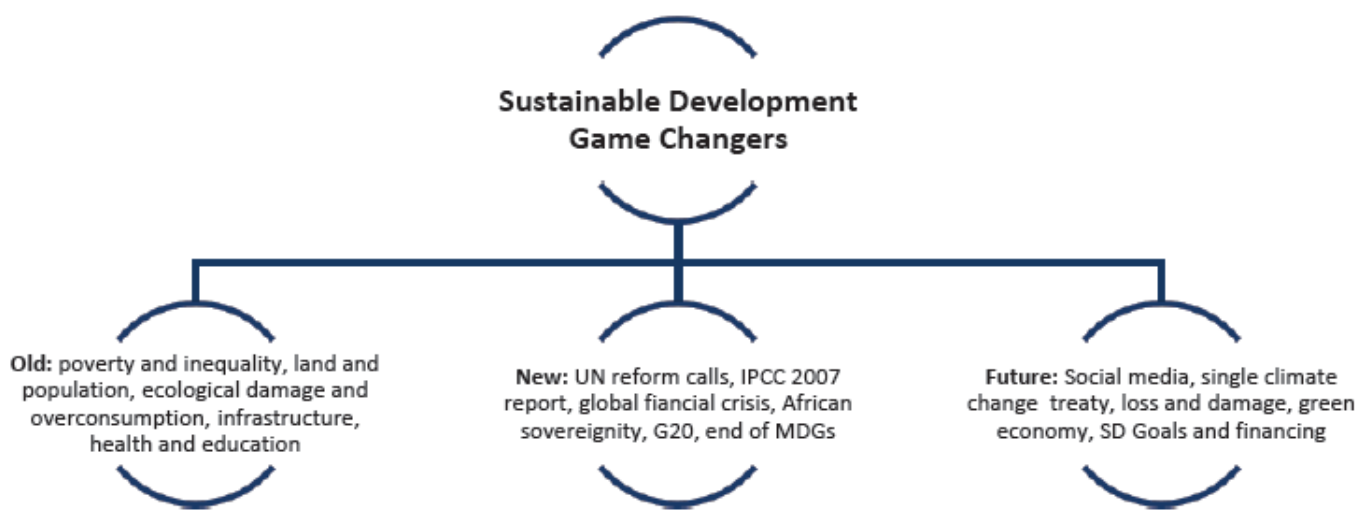

Figure 4: Sustainable development game changers (Source: Author)

The choice of which game changers to sample has been subjected to the author's judgment call given the historical, current and future trends towards the SD+ shift. Given the limitations of space, only a few of the identified game changers are discussed here to provide direction in the SD+'s emerging discourses. Over the years, global citizens have been battling with evidence needed to support the narrative that climate change is really taking place. Following the landmark Intergovernmental Panel on Climate Change (IPCC 2007) report, many sceptics were converted as the evidence confirmed that, indeed, climate change was happening and was happening fast. Hence, humanity needed to urgently do something drastic if global temperatures were to be maintained below the manageable two degrees of the pre- industrial temperature range. Since 2007, observed decadal global combined surface- air temperature over land and seasurface temperatures continued to be unequivocal in terms of their upward trend (Figure 5) and again, humanity is challenged to do more in terms of reducing GHG emissions. To those in the field of sustainable development and green growth, global temperature rise is one of the game changers of note. The world Metrological Organization (2013: 1) records the first decade of the 21st century (2001-2010) as the warmest since the 1850s and witnessed 'above-average precipitation, including one year- 2010- that broke all previous records'. Measured concentration of key GHGs showed increases of $158 \%$ for methane to 
$1,808 \mathrm{ppb}, 39 \%$ for carbon dioxide to $389 \mathrm{ppm}$ and $20 \%$ for nitrous oxide to $323.2 \mathrm{ppb}$ since pre-industrial times. This picture is frightening to responsible global citizens. As noticed by Ban Ki-Moon, the UN Secretary General: 'The danger posed by war to all of humanity - and to our planet - is at least matched by the climate crisis and global warming. The world has reached a critical stage in its efforts to exercise responsible environmental stewardship' (Smith School of Enterprise and the Environment 2010: viii).

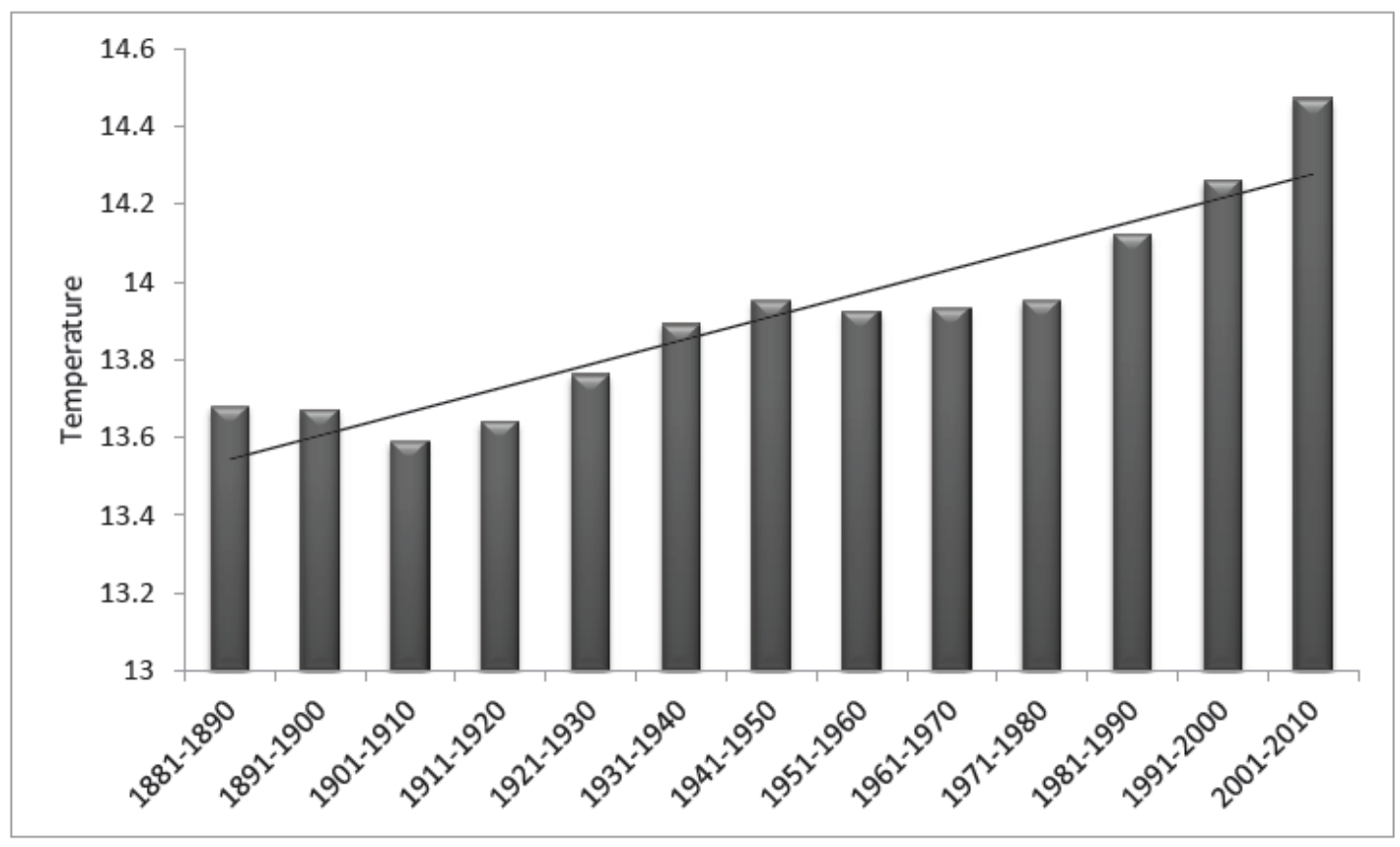

Figure 5: Trends in decadal global temperature rise (Source: Author [Data from World Metrological Organisation 2013: 4]) 
Another game changer linked to climate change has been the general increasing trend in all natural disasters that has the world talking on the concept of loss and damage. During the August 2008 3rd Session of the Ad Hoc Working Group on Long Term Cooperative Action under the UNFCCC, Munich Climate Insurance Initiative (MCII 2008) made a submission on insurance instruments for adapting to climate change. In the submission, the MCII indicated that the UNFCCC Bali Action Plan called for risk sharing and transfer modalities as part of addressing loss and damage in developing countries, especially those most vulnerable to climate change. This was in line with the provisions from Article 4.8 of the UNFCCC and Article 3.14 of the Kyoto Protocol. The MCll put forward two pillars: the prevention and insurance pillars. Under the Prevention Pillar, world leaders and their partners had to make the reduction of human and economic losses their top priority. Under the Insurance Pillar, world governments and partners had to come up with a Climate Insurance Pool. Since then, discussion on loss and damage has grown bigger with stronger voices from developing countries.

Warner et al. (2011) indicate that during COP17 in Durban, South Africa, negotiators reached consensus on a Subsidiary Body for Implementation (SBI) Work Programme on loss and damage that was established at COP16 with time lines from COP17 to COP18. Loss and damage came up as one of COP17 decisions (Decision 7/CP.17). During COP19 in Warsaw, the G77 and China presented a UNFCCC decision text to institute an International Mechanism on Loss and Damage (IMLD) (Third World Network 2013b). After lengthy deliberations (including walk outs by the $G 77$ and China), the Warsaw international mechanism for loss and damage was established (Third World Network 2013c). However, this did not happen although an interim measure to place the IMLD under the existing Cancun Adaptation Framework was agreed upon. Although still contested by the G77 and China, the establishment of the mechanism is a step in the right direction for many vulnerable Least Developed Countries and the Small Island Developing States. Loss and damage will remain a thorny issue under the proposed SD+ epoch. 
The 2008 global financial crisis confirmed a new world order as the rich nations from the northern hemisphere are now looking towards countries like China and the emerging Group of Five (G5) economies of Brazil, China, India, Mexico and South Africa for additional stimulus resources and leadership. Given this unfolding new world order, the call to embrace the concept SD+ makes sense as Africa and other continents now have the real chance to determine own sustainable futures and take the entire world along. The surrounds for sustainable development as popularized in Our Common Future of 1987 through the green growth platform to SD+ is shown in Figure 6, below.

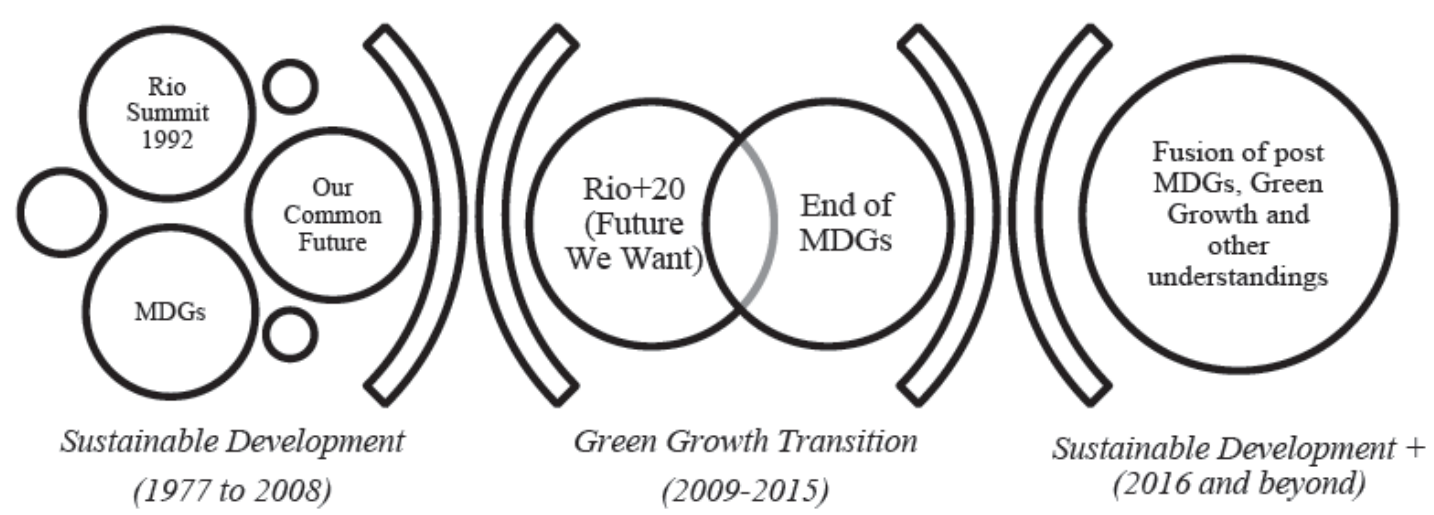

Figure 6: From sustainable development through green growth to SD+ (Source: Author)

What emerges from Figure 6 is a clearer picture that the world has been refining the sustainable development agenda. As we welcome the year 2016 and beyond, a more precise and general consensus is emerging regarding The Future We Do Not Want(or as some put it, The Future We Want). Many dots of different sizes in Figure 5 represent the historical nature in which the sustainable development debates emerged culminating in a consensus with the publication of Our Common Future that presented the most widely cited simple definition of sustainable development. Added to this list is a publication on 27 September in the 1960s entitled the Silent Spring by Rachel Carson that ignited environmental movement in the USA (Carson 1962). Globally, summits, conventions and treaties have emerged. The 1977 Stockholm Declaration of the United Nations Conference on the Environment came up with seven proclamations and 26 
principles. Proclamation 1 acknowledges man as having the contradictory power to both positively and negatively influence ecological systems (UNEP 1977). The Stockholm convention was the result of widespread acid rains that degraded freshwater systems in Eastern Europe. Proclamation 5 of the Declaration acknowledged a need for humanity to control rapidly growing populations whilst Proclamation 7 brought in the notion of citizen responsibility for the environment from governments to corporates and individuals.

Principle 1 gave birth to environmental rights that are now common across many global national constitutions. Other principles address issues ranging from nonrenewable resources, the role of the state in pollution prevention, the need to maintain economic and social development, coordinated approaches to development planning, stability in commodity prices etc. World leaders gathered in Rio de Janeiro, Brazil, from 3-14 June 1992. The outcome was the Rio Declaration on Environment and Development. The Rio Declaration presented 27 principles (UNEP 1992). The main aim of the Rio summit was to address key issues emerging from 'Our Common Future', especially given that the world now had some common definition on what sustainable development meant. Participants reaffirmed the Stockholm Declaration and sought to build on it. However, this was to be done within the context of broadening global partnerships. Out of the Rio Earth Summit emerged major UN conventions like the Convention to Combat Desertification (UNCCD), Convention on Biological Diversity (UNCBD) and the Framework Convention on Climate Change (UNFCCC). In Rio, global leaders once more confirmed the central role of human beings in addressing sustainable development (Principle 1) (UNEP 1992). Other principles focused on issues of equity, special treatment to least and developing countries, capacity development, the need to enact effective laws, the precautionary approach, need for environmental impact assessments for development projects, the role of women in environmental remediation and protection, rights of indigenous people and their communities, and the polluter pays fundamental (ibid.). 
Other initiatives surrounding the Our Common Future epoch of note include: the UN Decade of Education for Sustainable Development (2004-2014), the Millennium Development Goals (2000-2015), Tbilisi Declaration of 1977 on Environmental Education, UN Principles for Responsible Management Education (launched 2007), The King Reports on Corporate Governance (now under King III), and the Global Reporting Initiative (GR1) (see for example, PRME 2007; Adams and Petrella 2010; Nhamo and Swart 2012). Although The Future We Want still has a lot on the table, it may be achieved from a realization that there is no substitute for a sustainable global agenda. This is an agenda that puts people first, and sees all human beings as truly equal. It is an agenda that speaks to individuals first and has at the centre moral and ethics obligations. With this, The Future We Do Not Want- a future where there will be rampant joblessness, strife, poverty and fighting, may be avoided through the SD+ notion. In a recent paper, Heeks (2014) writes on a topic 'From the MDGs to the Post-2015 Agenda: Analyzing Changing Development Priorities'. His work concludes that the post 2015 agenda is 'the single most important force shaping the future of international development' (p. 1). In the lead up to and from the Rio+20 Summit, the idea of Sustainable Development Goals (SDGs) emerged as the post 2015 desired output. This resulted in the institution of the Rio+20 United Nations Open Working Group on SDGs and the Rio+20 High-Level Political Forum. Linked to the Open Working Group is the Expert Committee on Financing. Four key documents are recognized as shaping the post 2015 agenda, namely, Realizing the Future We Want for All (2012), A Renewed Global Partnership for Development (2013), A New Global Partnership (2013) and The Future We Want (2012). Drawing from the textual analysis on the highlighted key documents, Reeks found key threads that include the following aspects: food, health, global, growth, energy, education, development, economic access, financial, environmental, sustainable, rights, progress, women, support, partnerships, targets, resources, poverty, social, united, United Nations, systems, work, well, etc. 
Following the major line of argument that in SD+ there is better understanding of key issues Reeks just does that in terms of opening up this space (Table 1).

Table 1: From MGs to post 2015

\begin{tabular}{|c|c|c|c|}
\hline $\begin{array}{l}\text { MDG to Post } \\
2015\end{array}$ & Development Goals & $\begin{array}{l}\text { Development } \\
\text { Mechanism }\end{array}$ & $\begin{array}{l}\text { Development } \\
\text { Perspectives }\end{array}$ \\
\hline Diminution & $\begin{array}{ll}\text { - } & \text { MDG } 8 \text { with ICTs/Digital } \\
\text { - } & \text { Manufacturing } \\
\text { - } & \text { Insecurity }\end{array}$ & $\begin{array}{ll}\text { - } & \text { Traditional Devel- } \\
\text { opment Finance } \\
\text { Development } \\
\text { Strategy }\end{array}$ & N/A \\
\hline Continuity & $\begin{array}{ll}\text { - } & \text { Well-being } \\
\text { - } & \text { Infrastructure } \\
\text { - } & \text { Urban Development } \\
\text { - } & \text { Institutional Development } \\
\text { - } & \text { MDGs 1-6 } \\
\end{array}$ & - 'Informatics' & N/A \\
\hline $\begin{array}{l}\text { Some } \\
\text { Expansion }\end{array}$ & $\begin{array}{ll}\text { - } & \text { Rural/Agricultural } \\
& \text { Development } \\
\text { - } & \text { Services } \\
\text { - } & \text { Livelihoods } \\
\text { - } & \text { Growth and Jobs } \\
\text { - } & \text { Rights and Justice } \\
\end{array}$ & $\begin{array}{l}\text { - New Development } \\
\text { Finance } \\
\text { - Technovation } \\
\text { including data and } \\
\text { mobile }\end{array}$ & $\begin{array}{l}\text { Complex Adap- } \\
\text { tive Systems }\end{array}$ \\
\hline $\begin{array}{l}\text { Significant } \\
\text { Expansion }\end{array}$ & $\begin{array}{ll}\text { - } & \text { Open Development } \\
\text { - } & \text { Inclusive Development } \\
\text { - } & \text { Migration } \\
& \text { Environment and } \\
& \text { Sustainability }\end{array}$ & $\begin{array}{ll}\text { - } & \text { Development } \\
& \text { Projects } \\
\text { - } & \text { New Stakeholders }\end{array}$ & N/A \\
\hline
\end{tabular}

Source: Heeks (2013: 16)

From Table 1, Reeks (2014) raises the top 20 post 2015 development impact areas as follows: environment and sustainability, migration, inclusive development, new stakeholders, development projects, open development, complex adaptive systems, technovation, new development finance, rights and justice, growth and jobs, livelihoods, services, rural/agricultural development, urban development, N.IDGs 1-6, infrastructure, well-being, and informatics. There were also other issues that were diminishing in their importance, among them: $\triangle .1 D G 8$ (A Global Partnership for Development). Under environment and sustainability, the key issues emerging confirm climate change, disaster risk reduction, renewable energy, energy security, and waste management. The political shift towards accepting climate change discourses and science in the USA is also mentioned. 
In the SD+ generation there is no doubt that the world needs to continue on its sustainable and green economic recovery path - a path that places emphasis on a resource-efficient growth model.

\section{Conclusion}

In mathematics a ' + ' sign denotes addition or adding on top of. In the context of this article, the ' + ' adds further insight on the paradigm of sustainable development as popularized in the publication Our Common Future. The ' + ' sign also touches on emerging discourses on green growth to SD+. A'+' sign is not equal to any other signs such as 'minus', 'equal', 'multiplication', 'division' etc. Sadly, as the world moved in to implement sustainable development since Rio 1992, we have witnessed serious subtractions and divisions especially from powerful, so-called aid and donor nations. Goal posts are shifted during global development and sustainability discourses. At times, utter stubbornness is displaced. Now that the world has a better understanding on what sustainable development could entail, the time to act has come. World leaders and individuals have a better grasp of what a global financial crisis means and how it may be avoided, what climate change damage is and how citizens may adapt and mitigate it, what a resourceintensive development path means and how it may be changed, what poverty and joblessness are and can do to all citizens globally, and above all, the promises of the green growth agenda and how we can keep on refining it for a better world. All this is what the proposed concept of SD+ seeks to disaggregate leading to a better life for all global citizens. Since we now know, let us then act accordingly from both the moral and ethics perspectives.

\section{Acknowledgements}

The author thanks Exxaro Resources Limited for sponsoring the Chair in Business and Climate Change run under Unisa's Institute for Corporate Citizenship. 


\section{References}

Adams, C. and Petrella, L. 2010. Collaboration, connections and change: The UN Global Compact, the Global Reporting Initiative, Principles for Responsible Management Education and the Globally Responsible Leadership Initiative. Sustainability Accounting, Management and Policy Journal 1(2): 292-296.

African Development Bank (AfDB). 2013. Green growth Sierra Leon: Transitioning towards green growth-Stocktaking and the way forward Tunis: AfDB.

African Climate Finance Hub. 2012. Climate finance readiness: Preliminary approach and insights from efforts in southern Africa. Bonn: African Climate Finance Hub.

Boyle, J., Morphy, D. and Bernard, F. 2011. REDD+ after Cancun: Moving from negotiation to implementation. London: International Institute for Sustainable Development.

Brunner, R., Ali, F., Ambel, C., Aquino, P., Bautista, K., Bendandi, B, Karpati, A, Lai, K., BarbourMcKellar, J., Roos, M., Rudder, N., Soergel, E. and Valencia, N. 2010. Back to its roots:REDD+ via the CopenhagenAccord. Reconsidering Development 1(1): 1-10.

Cairns, J. (Jr). 2004. Ecological tipping points: A major challenge for experimental sciences. Asian Journal of Experimental Science 18(1\&2): 1-16.

Carson, R. 1962. Silent spring. New York: Houghton Mifflin Harcourt.

Corbera, E. and Schroeder, H. 2011. Governing and implementing REDD. Environmental Science \& Policy 14: 89-99.

Davis, C., Daviet, F., Nakooda, S. and Thuault, A 2009. A review of 25 readiness plan idea notes from the World Bank Forest Carbon Partnership Facility. WRI working paper. Washington, D.C.: World Resource Institute. www.wri.org/gfi/ (accessed 28 October 2014).

De Cock, K.M., W.M. El-Sadr and T.A Ghebreyesus. 2011. Game changers: Why did the Scale- Up of HIV treatment work despite weak health systems? Acquired Immune Deficiency Syndrome 57(2): S61-S63.

Development Bank of Southern Africa (DBSA). 2011. Programmes in support of transitioning South Africa to a green economy. Pretoria: Development Bank of Southern Africa. Department of Environmental Affairs (DEA). 2011. National Climate Change Response White Paper. Pretoria: DEA.

DeSombre, E.R. 2011. Global environmental governance for a new green economy. Review of Policy Research 28(5): 467-472.

Dixon, J.A. and Fallon, L.A. 1989. The concept of sustainability: Origins, extensions and usefulness for policy. Society and Natural Resources 2: 73-84.

Fioramonti, L. 2013. Gross Domestic Problem: The politics behind the world's most powerful number. London: Zed Books Ltd.

Global Green Growth Institute. 2014. Green Growth Best Practice: Synthesis of key findings. Seoul: Green Growth Best Practice Institute.

Green, D.D. and McCann, J. 2011. Benchmarking a leadership model for the green economy. Benchmarking: An International Journal 18 (3): 445-465.

Heeks, R. 2014. From the MDGs to the Post-2015 Agenda: Analyzing Changing Development Priorities. Manchester: Centre for Development Informatics. Http://www.unep.org /Documents 
.Multilingual/Default. asp? Document iD=97\&Article ID=1503/ (accessed 11 August 2013).

Hueting, R. 1990. The Brundtland Report: A matter of conflicting goals. Ecological Economics 2: 109117.

International chamber of Commerce (ICC). 2011. 10 conditions towards a transition to a green economy. Paris: ICC.

International Institute for Sustainable Development (IISD). 2013. Summary of the WARSAW Climate Change Conference: 11-23 November 2013. London: IISD.

Intergovernmental Panel on Climate Change (IPCC). 2007. Working Group II contribution to the Intergovernmental Panel on Climate Change, Fourth Assessment Report Climate Change 2007: Climate Change Impacts, Adaptation and Vulnerability, Summary for Policy makers. Geneva: Intergovernmental Panel on Climate Change.

Laszlo, C. and Cooper rider, D.L. 2010. Creating sustainable value: A strength-based whole System approach. Advances in Appreciative Inquiry 3: 17-33.

Munich Climate Insurance Initiative (MCII). 2008. Submission by the Munich Climate Insurance Initiative (MCII)- Insurance instruments for adapting to climate risks: A proposal for the Bali Action Plan. Munich: MCII.

Nhamo, G. 2010. Dawn of a new climate order: Reading between the USA-India-China partnerships. Politikon: South African Journal of Political Studies 37(2-3):351-374.

Nhamo, G. 2011. REDD(+) and the Global Climate Negotiating Regimes: Challenges and opportunities for Africa. South African Journal of International Affairs 18(3): 385-405.

Nhamo, G. 2013. Green economy readiness in South Africa: A focus on the national sphere of government. International Journal of African Renaissance Studies 8(1): 115-142.

Nhamo, G. and Inyang, E.A. 2011. Framework and tools for environmental management in Africa. Codesria: Senegal.

Nhamo, G. and Swart, R. 2012. A scholarly framework for measuring business responsibility to climate change in South Africa. Issues in Social and Environmental Accounting 6(1/2):50-71.

Pistorius, T. 2012. From RED to REDD+: The evolution of a forest-based mitigation approach for developing countries. Current Opinion in Environmental Sustainability 4: 638-645.

PRME. 2007. The principles for Responsible Management Education. Available at: http://www.unprme.org/the-6-principles/ (accessed 7 August 2013).

Rio Pavilion. 2012. Mozambique emerges as a green economy at Rio+20. http://www. riopavilion. org/storage/rio20_mozambiquegreeneconomy.pdf./ (accessed 3 March 2014).

Sandig, B. and Selting, M. 1997. Discourse styles. In Discourse as structure and process T.A. van Dijk ed., 138-156. London: Sage Publications.

Smith School of Enterprise and the Environment. 2010. National Strategy on Climate Change and Low Carbon Development for Rwanda Baseline Report. Oxford: Oxford University Press.

Tawney, L. and Weischer, L. 2011. Innovation and technology transfer: Supporting low carbon development with climate finance. Washington DC: World Resources Institute.

Third World Network. 2013a. Framework for REDD plus action, adopted in Warsaw. Warsaw: Third World Network 
Third World Network. 2013b. Developing countries propose text on international mechanism on loss and damage. Warsaw: Third World Network.

Third World Network. 2013c. COP 19 establishes Warsaw international mechanism for loss and damage. Warsaw: Third World Network.

United Nations. 1987. Our Common Future. New York: United Nations.

UNCSD (United Nations Commission on Sustainable Development). 2012. The Future We Want. United Nations Commission on Sustainable Development, Rio De Janeiro.

United Nations Development Programme (UNDP). 2012. Readiness for climate finance: framework for understanding what it means to be ready to use climate finance. New York: UNDP.

United Nations Development Programme (UNDP), Unicef, Oxfam and GFDRR. 2014. Disaster risk reduction makes development sustainable. New York.

UNEP. 1977. Declaration of the United Nations Conference on the Human Environment.

UNEP. 1992. Rio Declaration on Environmental and Development.http://www.unep.org/ Documents. Multilingual/Default.asp?documentid=78\&articleid=1163/ (accessed 11 August 2013).

UNEP. 2011. Towards a green economy: Pathways to sustainable development and poverty eradication-A synthesis for policy makers. Nairobi: UNEP.

UNFCCC. 1997. Kyoto Protocol.

Van Dijk, T.A. (1997). The study of discourse. In Discourse as structure and process. T.A. van Dijk ed., 1-34, London: Sage Publications.

Venter, O. and Koh, L.P. 2012. Reducing emissions from deforestation and forest degradation (REDD+): game changer or just another quick fix? Annals of the New York Academy of Sciences 1249: $137-150$.

Warner, K., Kreft, S. and Harmeling, S. 2011. Analysis: Loss \& damage related outcomes of COP 17 in Durban. Berlin: Loss and Damage Initiative.

World Metrological Organization. 2013. The global climate change 2001-2010: A decade of climate extremes summary report. Geneva: World Metrological Organization.

Zheng, R. 2010. The game changer: Transforming the biopharmaceutical landscape through single-use technologies. BioProcess International 4-9. 